\title{
STUDI KINETIKA PEMBERIAN BAWANG PUTIH (Allium sativum) PADA GIGI BERLUBANG DALAM MENGURANGI RASA NYERI
}

\author{
Maryana Dwi Atika ${ }^{* 1}$ \\ ${ }^{1}$ Program Studi Pendidikan Kimia, FMIPA, Universitas Negeri Padang, Indonesia \\ J1. Prof. Dr. Hamka Air Tawar Padang, Sumatera Barat \\ *e-mail : maryanadwiatika@gmail.com
}

\begin{abstract}
Abstrak. Studi ini bertujuan untuk membuat tumbukan dari bawang putih terhadap gigi berlubang dalam mengurangi rasa nyeri. Metode yang dilakukan adalah eksperimen dan uji katalitik secara langsung. Tahapan pertama dilakukan dengan penumbukan/penghalusan dari bawang putih. Uji aktivitas langsung dilakukan dengan variasi ${ }^{(8)}$ tiga kali oles minimal 30 menit setiap hari selama tujuh hari. Hasil eksperimen membuktikkan bahwa penumbukkan bawang putih dapat mengurangi rasa nyeri pada gigi berlubang. Kondisi optimum ${ }^{(9)}$ penumbukan bawang putih tercapai pada tiga kali oles minimal 30 menit setiap hari dalam tujuh hari. Penyembuhan ini diduga karena aktivitas katalitik tumbukan $^{(21)}$ bawang putih (Allium sativum) ${ }^{(16)}$ dalam mengurangi rasa nyeri pada gigi berlubang.
\end{abstract}

Keywords : bawang putih, gigi berlubang, katalitik, tumbukan, nyeri

\section{PENDAHULUAN}

Dalam kehidupan sehari-hari banyak sekali perubahan yang terjadi, baik secara makroskopis maupun mikroskopis. Perubahan yang terjadi disebabkan oleh beberapa faktor, salah satunya adalah faktor biologis. Faktor biologis yaitu segala sesuatu yang berhubungan dengan makhluk hidup. Contoh dari biologis yaitu ada pada manusia, tumbuhan maupun hewan. Makhluk hidup tersebut juga mengalami perubahan baik internal maupun eksternal.

Perubahan yang terjadi mengahasilkan sesuatu baru yang sifatnya berbeda dengan sebelumnya. Sama halnya dengan reaksi ${ }^{(2)}$ dalam tubuh makhluk hidup juga terjadi reaksi yaitu reaksi kimia. Reaksi kimia sangat berperan penting dalam kehidupan manusia $^{(3)}$. Tanpa adanya reaksi kimia maka tidak ada hal baru yang akan muncul di kehidupan ini. Selain itu, akan banyak hal-hal lama atau kadaluarsa yang tidak berubah menjadi hal baru. Reaksi kimia terjadi dimana-mana, baik dalam tubuh manusia ataupun lingkungan sekitar.

Dalam reaksi kimia terdapat katalitik $^{(22)}$. Katalitik yaitu zat yang dapat membantu percepatan terjadinya suatu reaksi kimia tersebut. Peran katalis dalam reaksi kimia sangat dibutuhkan. Karena jiakalau tidak ada katalis ${ }^{(1)}$ dalam reaksi kimia maka reaksi tersebut akan lama dan hasilnya tidak sesuai. Dalam reaksi kimia, katalis tidak berperan sebagai reaktan maupun produk. Namun, katalis itu 
sebagai pemicu yang memungkinkan terjadinya reaksi secara cepat.

Salah satu contoh katalis yaitu enzim ${ }^{(19)}$. Enzim merupakan biokatalis yang terdapat dalam tubuh manusia yang berupa protein ${ }^{(20)}$. Protein merupakan enzim yang tidak habis bereaksi walaupun sudah mengalami reaksi dalam tubuh manusia. Dalam tubuh manusia, proses biologis sel membutuhkan enzim dalam bereaksi agar berlangsung cukup cepat. Semua proses reaksi kimia yang terjadi di dalam tubuh manusia dapat terjadi secara cepat karena adanya katalis atau yang mempercepat reaksi kimia ini terjadi.

Pada proses kerusakan ${ }^{(4)}$ gigi juga merupakan reaksi kimia karena adanya enzim yang terdapat dalam mulut. Enzim tersebut mampu membuat gigi berlubang ${ }^{(23)}$ karena adanya plak dari sisa-sisa makanan ${ }^{(5)}$ yang dikonsumsi. Plak pada gigi berasal dari sisa makanan yang mengandung gula. Plak ini akan di ubah oleh bakteri alami yang ada dalam mulut menjadi asam ${ }^{(31)}$. Plak yang terbentuk akan melekat pada gigi karena adanya perpaduan dari bakteri ${ }^{(6)}$, asam ${ }^{(8)}$, sisa makanan dan air liur. Sehingga asam yang ada pada plak ${ }^{(27)}$ secara cepat akan mengikis lapisan-lapisan gigi hingga membentuk lubang pada gigi dan masalah lainnya pada gigi. Gigi juga mengandung kalsium ${ }^{(28)}$.

Masalah pada gigi seperti gigi berlubang akan menimbulkan rasa sakit yaitu nyeri yang berkesinambungan bila tak segera di obati. Terutama jika kondisi gigi berlubang semakin buruk, maka rasa nyeri pun tak kunjung sembuh sehingga memaksakan untuk mencabut gigi berlubang tersebut. Dalam hal ini, ada beberapa bahan alami yang mampu mengurangi rasa nyeri yang menyerang gigi, seperti minyak cengkeh, bawang merah, bawang putih $^{(17)}$, daun jambu biji, jahe dan masih banyak lagi.

Allium sativum merupakan bahan alami ${ }^{(10)}$ yang sangat efektif dalam mengurangi rasa nyeri pada gigi berlubang. Bawang putih merupakan tanaman dari genus Allium yang digunakan sebagai bahan utama dalam bumbu dasar masakan. Bawang putih juga mengandung senyawa-senyawa ${ }^{(12)}$ sulfur yang termasuk zat kimia ${ }^{(11)}$ yaitu alilin. Alilin merupakan asam amino yang berfungsi sebagai antibiotik. Selain alilin terdapat zat lain yang disebut allicin ${ }^{(18)}$ yang berfungsi sebagai antiseptik dan dapat menghambat pertumbuhan mikroorganisme ${ }^{(24)}$ serta membunuh bakteri.

Allium sativum bisa digunakan sebagai obat dalam mengurangi rasa nyeri pada gigi berlubang dengan menambahkan garam ${ }^{(26)}$. Untuk pengurangan rasa nyeri ini tergantug dengan seberapa buruknya keadaan gigi berlubang. Bila gigi sudah berlubang menengah atau sebagian maka resep yang paling efektif adalah digunakan 30 menit setiap hari dalam tiga kali oles selama tujuh hari. Metode yang dilakukan yaitu penumbukkan atau ekstrak dari bawang putih itu sendiri ${ }^{(35)}$. Cara ini sangat ampuh dalam mengurangi rasa nyeri yang menyiksa diri sendiri.

\section{METODE}

Pada metode ini terdiri dari dua hal, yaitu alat dan bahan dan prosedur kerja.

1. Alat dan Bahan

Untuk peralatan yang digunakan adalah pisau cutter (Kenko), sendok makan (Stainless Steell OB NO. 303), cobek batu (Sisilia), wadah plastik (Tupperware) dan kamera HP (Asus). Untuk bahan yang digunakan adalah bawang putih yang di beli di kedai sayuran jalan Cenrdawasih dan garam dapur yang dibeli di warung jalan patengganggan Gg. L. 


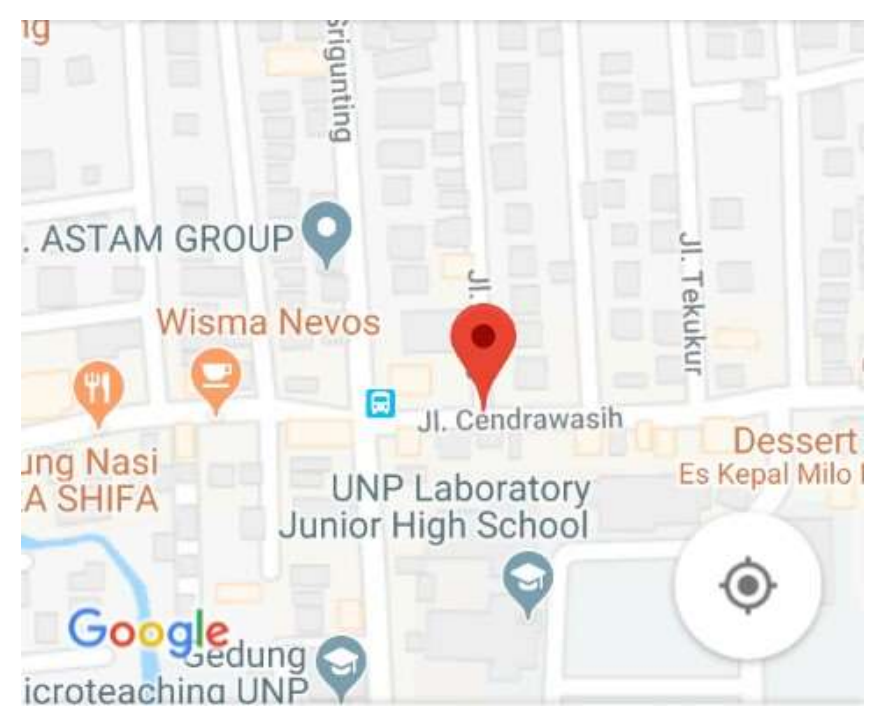

\section{Prosedur Kerja}

- Penyiapan Sampel

Sampel di beli dari kedai sayuran di jalan Cendrawasih sebanyak satu ons. Kemudian sampel yang di ambil sebanyak satu ons dan di kupas kulitnya. Lalu di cuci dan di potong menjadi dua bagian dengan menggunakan pisau cutter.

- Pembuatan Ekstrak Bawang Putih

Ekstrak di buat dengan cara penumbukkan bawang putih di atas cobek batu. Potongan bawang putih sebanyak satu ons di masukkan kedalam cobek batu lalu di tambahkan garam tiga sendok. Kemudian di tumbuk sampai bawang putih halus dan bercampur rata dengan garam dapur. Setelah halus pindahkan tumbukan bawang putih ke dalam wadah plastik dengan menggunakan sendok makan.

- Pengujian ekstrak

Ekstrak di uji pada gigi geraham yang berlubang. Tumbukan bawang putih dimasukkan kedalam gigi berlubang dan di olesi di sekitaran gigi berlubang sebanyak setengah sendok makan. Lalu diamkan sekitar 30 menit. Pengujian ini dilakukan tiga kali oleh setiap hari selama 30 menit dalam jangka waktu tujuh hari.

Ekstrak yang sudah jadi di cobakan pada gigi berlubang dengan variasi setengah sendok makan yang dilakukan tiga kali oles setiap hari selama 30 menit dalam jangka waktu tujuh hari. Hasil pengujian tumbukan bawang putih ditanyakan pada yang di uji gigi berlubangnya.

Metode penumbukan bawang putih ini dapat dibuat dengan diagram alir.

Mengupas bawang putih sebanyak satu ons 


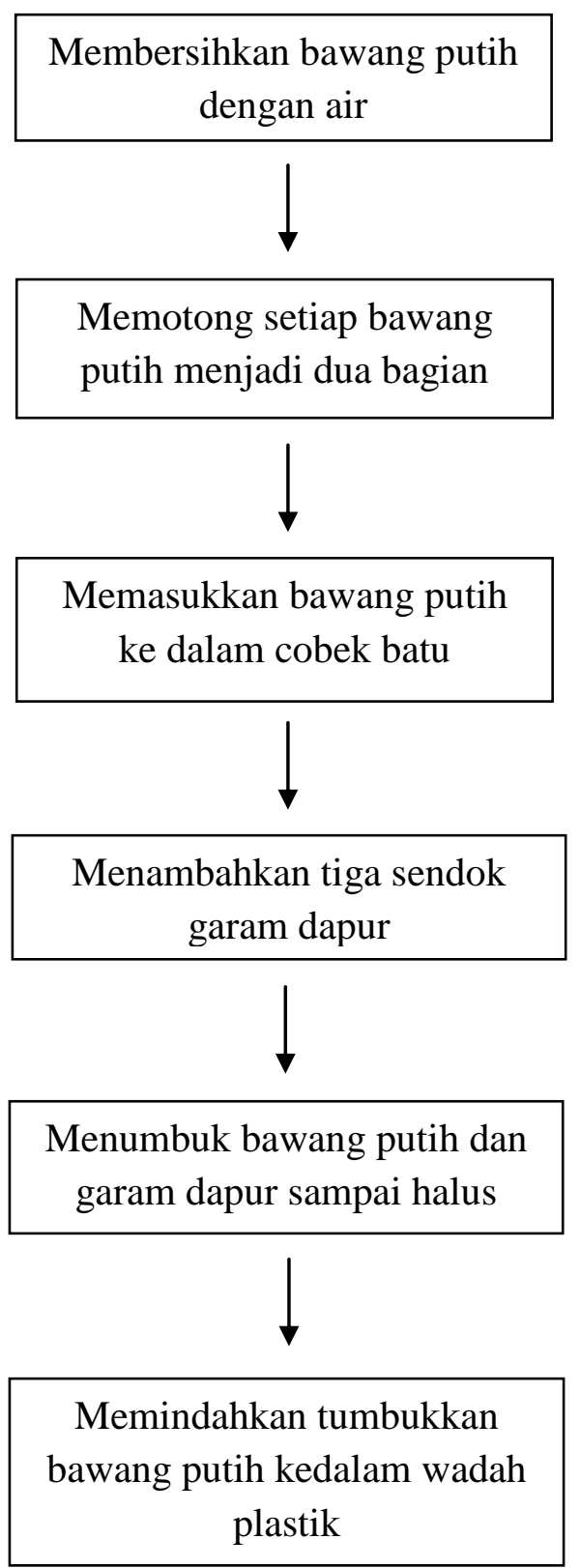

\section{HASIL}

1. Hasil Pembuatan

Hasil pembuatan ekstrak diperoleh sebanyak tiga sendok makan dari satu ons bawang putih dan tiga sendok makan garam dapur. Hal ini dapat dilihat pada gambar berikut ini : 
Bawang putih

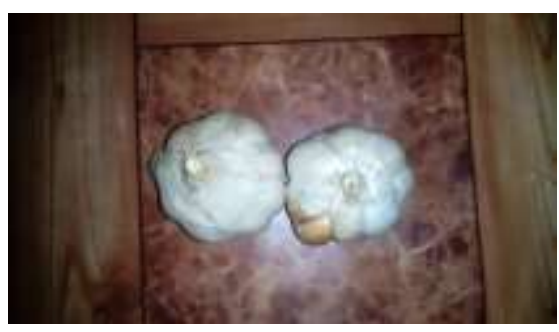

Garam dapur

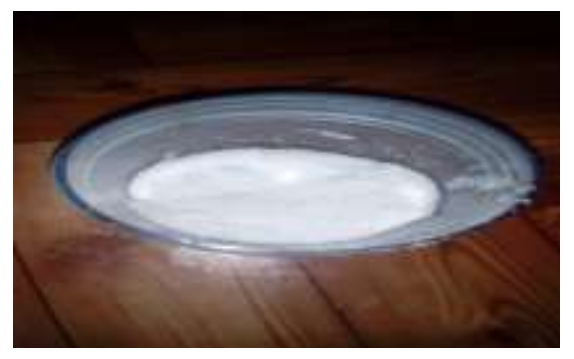

Tumbukkan bawang putih

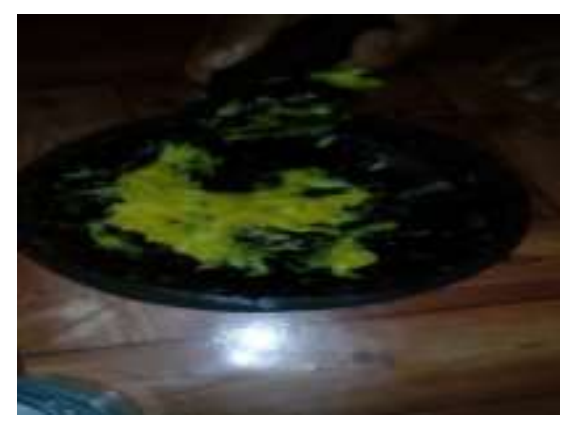

\section{Hasil Uji Coba}

Pengujian dilakukan kepada orang yang mengalami nyeri pada gigi berlubangnya.

Gigi berlubang

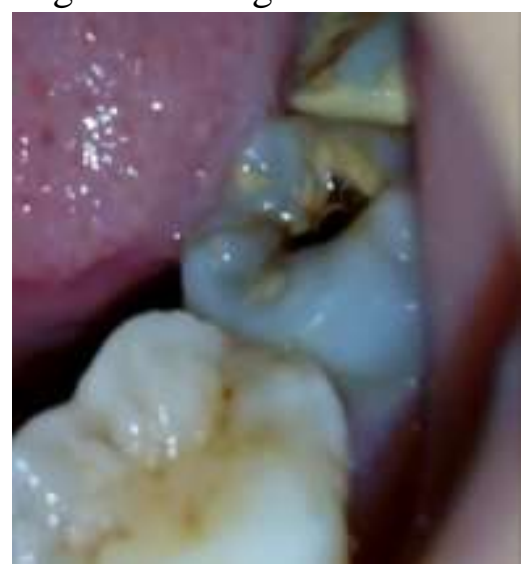


Dan ternyata pengujian ini berhasil dengan tiga kali oles setiap hari selama 30 menit dalam jangka waktu tujuh hari, sebagaimana yang terlihat pada tabel ini.

\begin{tabular}{|c|c|}
\hline Hari & $\begin{array}{c}\text { Tingkat rasa } \\
\text { nyeri }\end{array}$ \\
\hline 1 & $95 \%$ \\
\hline 2 & $80 \%$ \\
\hline 3 & $65 \%$ \\
\hline 4 & $50 \%$ \\
\hline 5 & $35 \%$ \\
\hline 6 & $20 \%$ \\
\hline 7 & $5 \%$ \\
\hline
\end{tabular}

Keterangan : semakin lama jangka waktu pemakaian akan semakin menurunkan rasa nyeri pada gigi berlubang.

\section{PEMBAHASAN}

1. Pembuatan

Dalam proses pembuatan tumbukkan bawang putih ini terdapat kendala yaitu pada cobek batunya yang ukurannya kecil. Sehingga agak sulit menghaluskan satu ons bawang putih dan garam secara cepat. Namun, metode yang digunakan cukup sederhana dan mudah dilakukan karena hanya menghaluskan bawang putihnya. Garam dapur yang digunakan yaitu garam $^{(33)}$ dapur yang halus agar lebih cepat bercampur rata dengan bawang putihnya ketika agak mulai halus. Dalam pembuatan resep ini langkah pertama yaitu mengupas kulit bawang putih dan mencucinya sampai bersih. Ini dilakukan agar bawang putih bersih dan hasil dari tumbukan juga berwarna khas bawang putih. Lalu memotong bawang putih menjadi dua bagian tiap siungnya agar saat penumbukkan lebih mudah dan cepat halusnya. Sebelum di tumbuk maka diberi garam dapur untuk mempermudah dan mempercepat proses penghalusan bawang putihnya. Hal yang perlu diperhatikan pada proses pembuatan resep ini adalah tekstur bawang putih yang dihasilkan harus benar-benar halus dan bercampur rata dengan garam dapurnya ${ }^{(29)}$. Agar mudah saat mengolesi gigi yang nyeri. Jadi, proses penumbukkan harus dilakukan secara berulang agar semuanya dapat halus sempurna.

2. Uji Coba 


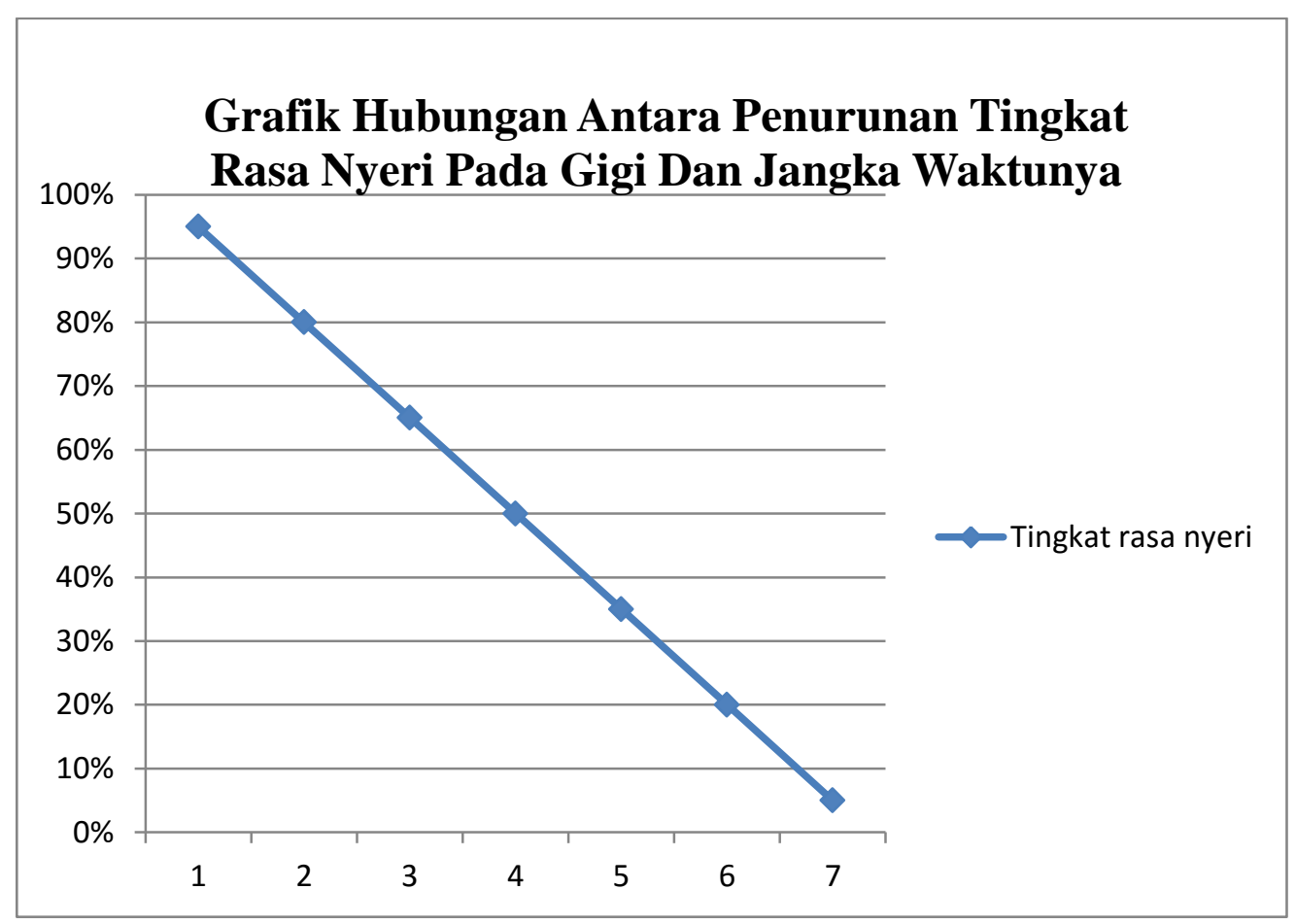

Berdasarkan dari grafik diatas, bahwa diketahui semakin lama pemakaian tumbukkan bawang putih terhadap gigi berlubang dapat menurunkan ${ }^{(13)}$ rasa nyeri pada gigi. Dari hasil uji coba pemakaian jangka panjang, tumbukkan bawang putih memberi efek positif pada rasa nyeri. Hal ini terjadi karena pemakaian tumbukkan bawang putih ini dilakukan secara teratur selama tujuh hari. Dan kondisi maksimum yang dihasilkan yaitu pada hari ketujuh yang memberikan rasa nyeri pada gigi semakin menurun yaitu $5 \%$.

3. Interaksi

Penyebab gigi berlubang yaitu karena adanya plak dari sisa-sisa makanan yang dikonsumsi. Hal ini menyebabkan sisa-sisa makanan semakin lama semakin menumpuk dan menyebabkan bakteri mengubahnya menjadi asam. Plak yang ada pada gigi itu berasal dari perpaduan antara bakteri, asam, sisa makanan, dan air liur. Sehingga asam yang ada pada plak secara cepat akan mengikis lapisan-lapisan gigi hingga membentuk lubang pada gigi dan masalah lainnya pada gigi. Hal ini menyebabkan rasa sakit mulai melanda pada gigi karena rusaknya giginya. Faktor pemicu lainnya yang menyebabkan gigi berlubang atau rusak yaitu karena sering memakan makanan yang mengandung gula secara berlebih dan setelah itu tidak segera menyikat atau membersihkannya. Sehingga banyak sisa makanan yang bersarang di gigi.

Kerusakan gigi ini tidak memandang usia ataupun gender ${ }^{(14)}$. Baik muda atau tua dan wanita maupun pria. Hal ini terjadi karena kita tidak dapat menjaga kebersihan gigi sehingga gigi kita pun tidak bersih. Kerusakan gigi merupakan proses kimia yang membutuhkan katalis yaitu enzim yang terdapat dalam mulut. Enzim ini mampu membuat gigi berlubang karena disebabkan adanya plak dari sisa-sisa makanan yang dikonsumsi. 
Bawang putih atau nama latinnya adalah Allium sativum memiliki zat kimia yaitu allilin yang merupakan asam amino yang berfungsi sebagai antibiotik.

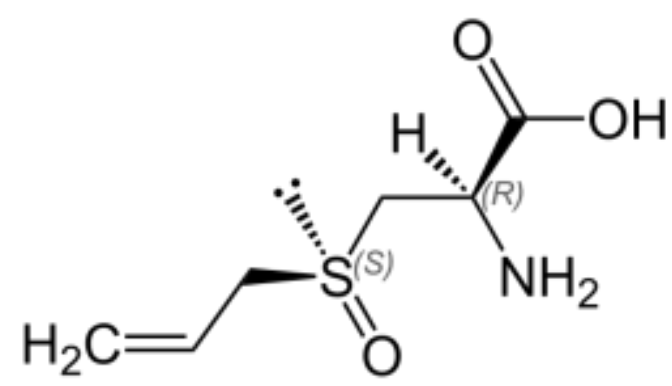

Bawang putih segar mengandung allilin sehingga enzim allinase bisa mengubah allilin menjadi allicin. Allicin ini yang menyebabkan aroma segar ${ }^{(15)}$ pada bawang putih. Allicin berfungsi sebagai antiseptik dan dapat menghambat pertumbuhan mikroorganisme serta membunuh bakteri. Allicin ini merupakan mekanisme pertahanan diri bawang putih terhadap bakteri.

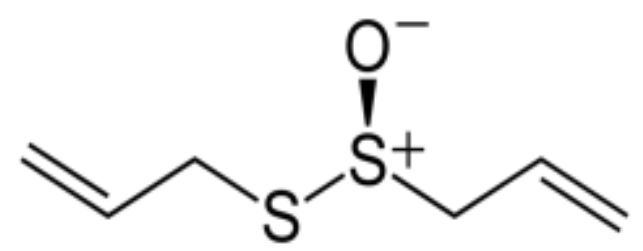

Senyawa ini mampu mengurangi bakteri yang terus berkembang dalam gigi berlubang. Sehingga rasa nyeri pada gigi berlubang juga berkurang. Saat bawang putih dihaluskan maka produksi allicin pada bawang putih semakin banyak karena allicin terbentuk karena rusaknya struktur bawang putih menjadi tidak utuh lagi dan menyebabkan bau khas bawang putih. Hal itu dapat membunuh bakteri yang terdapat pada gigi berlubang.

Selain itu, garam dapur juga berfungsi sebagai disinfektan alami. Air ${ }^{(32)}$ asin yang mudah dan efektif untuk menyembuhkan sakit gigi. Garam juga dapat berinteraksi dengan suatu sistem biologis ${ }^{(34)}$. Garam ${ }^{(30)}$ memiliki kandungan anti-bakteri dan antiinflamasi yang berguna untuk meredakan sakit pada gigi berlubang.

\section{KESIMPULAN}

1. Tumbukkan bawang putih bisa dibuat dari satu ons bawang putih dan tiga sendok garam dapur yang dihaluskan dengan menggunakan cobek batu.

2. Tumbukkan bawang putih dapat mengurangi rasa nyeri pada gigi berlubang dengan kondisi optimum tiga kali oles setiap hari selama 30 menit dalam jangka waktu tujuh hari.

3. Tumbukkan bawang putih dapat mengurangi rasa nyeri pada gigi berlubang karena adanya senyawa allilin dan allicin yang berfungsi sebagai antiseptik dan dapat menghambat pertumbuhan mikroorganisme serta membunuh bakteri. 


\section{REFERENSI}

[1] Sanjaya, H. (2018) "DEGRADASI METIL VIOLET MENGGUNAKAN KATALIS ZnO-TiO2 SECARA FOTOSONOLISIS”, EKSAKTA: Berkala Ilmiah Bidang MIPA, 19(1), pp. 91-99. doi: 10.24036/eksakta/vol19-iss1/131.

[2] Ruswandi, R. (2018) "Determination of Fructose Content resulted by Inulin Hydrolysis with DNS as Oxidizer", EKSAKTA: Berkala Ilmiah Bidang MIPA, 19(1), pp. 14-23. doi: 10.24036/eksakta/vol19-iss1/102.

[3] Yanuar, F., Tillah, M. and Devianto, D. (2018) "Modeling of Human Development Index Using Ridge Regression Method", EKSAKTA: Berkala Ilmiah Bidang MIPA, 19(2), pp. 1-11. doi: 10.24036/eksakta/vol19-iss2/134.

[4] Dinata, M. and Soehardi, F. (2018) "Factor Analysis of Physics Chemistry Waters that Affects Damage Safety Cliff on the Outskirts of River Siak", EKSAKTA: Berkala Ilmiah Bidang MIPA, 19(2), pp. 46-49. doi: 10.24036/eksakta/vol19-iss2/143.

[5] Susilaningrum, D. (2017) "PEMODELAN REGRESI LOGISTIK PADA FAKTOR YANG MEMPENGARUHI PHBS PADA RUMAH TANGGA PENDERITA TBC DI PESISIR SURABAYA”, EKSAKTA: Berkala Ilmiah Bidang MIPA, 18(02), pp. 121128. doi: 10.24036/eksakta/vol18-iss02/65.

[6] Putri, D., Fifendy, M. and putri, M. (2018) "DIVERSITAS BAKTERI ENDOFIT PADA DAUN MUDA DAN TUA TUMBUHAN ANDALEH (Morus macroura miq.)", EKSAKTA: Berkala Ilmiah Bidang MIPA, 19(1), pp. 125-130. doi: 10.24036/eksakta/vol19-iss1/122.

[7] Syafei, N. (2017) "ANALISA FENOMENA KOROSI PELAT PIPA BAJA KARBON API 5L-X65 DALAM LARUTAN 250 ML ASAM ASETAT DAN 4750 ML AQUADES PADA KONDISI GAS CO2 DAN H2S JENUH PADA SUHU RUANG", EKSAKTA: Berkala Ilmiah Bidang MIPA, 18(02), pp. 113-120. doi: 10.24036/eksakta/vol18-iss02/63.

[8] Ruswandi, R. (2018) "Determination of Fructose Content resulted by Inulin Hydrolysis with DNS as Oxidizer", EKSAKTA: Berkala Ilmiah Bidang MIPA, 19(1), pp. 14-23. doi: 10.24036/eksakta/vol19-iss1/102.

[9] Samah, S. (2017) "KARAKTERISASI PLASTIK BIODEGRADABEL DARI LDPEg-MA DAN PATI TANDAN KOSONG SAWIT", EKSAKTA: Berkala Ilmiah Bidang MIPA, 18(02), pp. 30-38. doi: 10.24036/eksakta/vol18-iss02/48.

[10] Sari, A. (2017) "POTENSI ANTIOKSIDAN ALAMI PADA EKSTRAK DAUN JAMBLANG (Syzigium cumini (L.) Skeels)", EKSAKTA: Berkala Ilmiah Bidang MIPA, 18(02), pp. 107-112. doi: 10.24036/eksakta/vol18-iss02/61.

[11] Ningsih, S. K. (2017) "SINTESIS DAN KARAKTERISASI NANOPARTIKEL ZnO DOPED Cu2+ MELALUI METODA SOLGEL", EKSAKTA: Berkala Ilmiah Bidang MIPA, 18(02), pp. 39-51. doi: 10.24036/eksakta/vol18-iss02/51.

[12] Setianto, S. (2017) “ANALISA KUANTITATIF CAMPURAN SENYAWA OKSIDA SEBAGAI DASAR IDENTIFIKASI KANDUNGAN BAHAN SUMBER DAYA ALAM Studi Kasus : Kandungan Mineral pada Pasir Besi di Pesisir Pantai Selatan, Jawa Barat", EKSAKTA: Berkala Ilmiah Bidang MIPA, 18(02), pp. 173-177. doi: 10.24036/eksakta/vol18-iss02/74.

[13] Horiza, H. (2018) "The influence of the use of activated carbon Fibres of the cane Against the drop in Salinity In the well Dig In RT 003 RW 006 Village Cape 
Town Unggat Tanjungpinang Year 2017', EKSAKTA: Berkala Ilmiah Bidang MIPA, 19(1), pp. 1-6. doi: 10.24036/eksakta/vol19-iss1/97.

[14] Rahmi H.G, I. (2017) “TELAAH FAKTOR-FAKTOR YANG MEMPENGARUHI STATUS GIZI BALITA DI KOTA PADANG BERDASARKAN BERAT BADAN PER TINGGI BADAN MENGGUNAKAN METODE CART”, EKSAKTA: Berkala Ilmiah Bidang MIPA, 18(02), pp. 86-99. doi: 10.24036/eksakta/vol18-iss02/59.

[15] Horiza, H., Azhar, M. and Efendi, J. (2017) "EKSTRAKSI DAN KARAKTERISASI INULIN DARI UMBI DAHLIA (Dahlia sp.L) SEGAR DAN DISIMPAN", EKSAKTA: Berkala Ilmiah Bidang MIPA, 18(01), pp. 31-39. doi: 10.24036/eksakta/vol18-iss01/14.

[16] SARWADANA, SANG MADE; ALIT GUNADI, I GUSTI. 2017. Potensi Pengembangan Bawang Putih (Allium Sativum L.) Dataran Rendah Varietas Lokal Sanur. Vol. 26, No.1

[17] Dwi Sulistyoningsih, Budi Santosa, Didik Sumanto. 2009. EFEKTIVITAS LARUTAN BAWANG PUTIH DALAM MEMBUNUH LARVA Aedes aegypti. Vol. 2, No. 2.

[18] Fatmawaty Fatmawaty, Muhammad Hanafi, Rosmalena Rosmalena, Vivitri Dewi Prasasty. 2015. SKRINING IN SILICO POTENSI SENYAWA ALLICIN DARI ALLIUM SATIVUM SEBAGAI ANTIPLASMODIUM. Vol. 17, No. 2.

[19] Muhammad Zakiyul Fikri, Tati Nurhayati, Ella Salamah. 2014. EKSTRAKSI DAN KARAKTERISASI PARSIAL EKSTRAK KASAR ENZIM KATEPSIN DARI IKAN PATIN [EXTRACTION AND PARTIAL CHARACTERIZATION OF CRUDE ENZYMES CATHEPSIN FROM CATFISH]. Vol. 25, No. 1.

[20] DWIRINI RETNO GUNARTI, HANIFAH RAHMI, MOHAMAD SADIKIN. 2013. ISOLATION AND PURIFICATION OF THIAMINE BINDING PROTEIN FROM MUNG BEAN. Vol. 20, No. 1.

[21] Yuliansyah Yuliansyah, Hadi Ali, Priyo Pratomo. 2015. KEPADATAN CAMPURAN DENGAN VARIASI TUMBUKKAN TERHADAP AC-WC GRADASI HALUS. Vol. 3, No. 2.

[22] Hary Sulistyo, Muhammad Fadjri, Nuryoto Nuryoto. 2010. KINETIKA REAKSI OKSIDASI KATALITIK FERO SULFAT DARI LIMBAH BESI DALAM REAKTOR LULUHAN. Vol. 13, No. 2.

[23] Indriati, Indriati,, Edy Kurniawan, Titi Hariyati. 2016. DAYA HAMBAT GETAH TANAMAN JARAK PAGAR (Jatropha curcas Linn) TERHADAP PERTUMBUHAN BAKTERI Streptococcus mutans PENYEBAB GIGI BERLUBANG. Vol. 2, No. 1.

[24] Indah Riwayati, Indah Hartati, Laeli Kurniasari. 2012. TEKNOLOGI IMOBILISASI SEL MIKROORGANISME PADA PRODUKSI ENZIM LIPASE. Vol. 1, No. 1.

[25] Farida Ariyani, Jovita Tri Murtini, Gunawan Yusuf, Irma Hermana. 2012. Pemanfaatan Ekstrak Air Daun Jambu Biji Sebagai Antioksidan Alami Pada Pengolahan Patin Asin. Vol. , No. 1.

[26] Lubis, A. P., \& Zainul, R. (2018, November 5). Interaksi Molekuler Amonium Hidroksida. https://doi.org/10.31227/osf.io/jht3b 
[27] Febriani, S. S., Yolanda, T., Arianti, V. A., \& Zainul, R. (2018, October 12). A Review Solid Stated : Principles and Methode. https://doi.org/10.31227/osf.io/7us4x

[28] Alfionita, T., \& Zainul, R. (2019, January 29). Calcium Chloride (CaCl2) : Characteristics and Molecular Interaction in Solution. https://doi.org/10.31227/osf.io/m37xj

[29] Yuliani, F., \& Zainul, R. (2018, November 13). Analisis Termodinamika Molekul Magnesium Sulphate (MgSO4). https://doi.org/10.31227/osf.io/uxz4y

[30] Jumalia, R., \& Zainul, R. (2019, February 3). Natrium Karbonat : Termodinamika dan Transport Ion. https://doi.org/10.31227/osf.io/y2vq9

[31] Warlinda, Y. A., \& Zainul, R. (2019, January 29). Asam Posfat (H3PO4): Ionic Transformation of Phosphoric Acid in Aqueous Solution. https://doi.org/10.31227/osf.io/s3y8v

[32] Nasution, A. W., Putri, R. N., Mayendra, E., \& angraini, L. p. (2019, April 10). MENGKAJI KARAKTERISTIK PENGGUNA TEKNOLOGI PENGOLAHAN AIR BERSIH DI INDONESIA. https://doi.org/10.31227/osf.io/as8vx

[33] Y., \& Zainul, R. (2018, November 18). SILVER SULFATE (Ag2SO4): MOLECULAR ANALYSIS AND ION TRANSPORT. https://doi.org/10.31227/osf.io/n8g9k

[34] Artika, P. I., \& Zainul, R. (2018, November 19). Potassium Bromide (KBr): Transformasi ionik dan sifat temodinamika dalam Larutan. https://doi.org/10.31227/osf.io/a5hyz

[35] Dinata, A. A., Rosyadi, A. M., Hamid, S., \& Zainul, R. (2018, October 15). A Review CHEMICAL VAPOR DEPOSITION : PROCESS AND APPLICATION. https://doi.org/10.31227/osf.io/yfeau 